\title{
Quantitative changes in DNA methylation induced by monochromatic light in barley regenerants obtained by androgenesis
}

\author{
Zmiany ilościowe metylacji DNA indukowane przez światło monochromatyczne \\ u regenerantów jęczmienia uzyskanych na drodze androgenezy
}

\author{
Patrycja Siedlarz, Sławomir Bany, Krystyna Rybka $\bowtie$
}

\author{
Department of Plant Biochemistry and Physiology \\ Plannt Breeding and Acclimatization Institute - National Research Institute, 05-870 Radzików, Poland \\ $\triangle$ k.rybka@ihar.edu.pl
}

\begin{abstract}
Changes in DNA methylation are one of the best known mechanisms of epigenetic regulation of gene expression, which in the process of induced androgenesis is associated with reprogramming of haploid microspores development towards the formation of embryos, as a result of exposure of anthers in ears and then anthers culture in vitro to stress factors. The aim of the study was to test the hypothesis of whether the use of monochromatic light during induced androgenesis might be associated with epigenetic phenomena. The experiments were carried out on DH plants of spring barley (Hordeum vulgare L.) obtained by androgenesis modified by monochromatic light: blue, green and red. A quantitative evaluation of the effect of light on the degree of DNA methylation was performed using RP-HPLC for the comparison of regenerants obtained under standard, control conditions (darkness) with those obtained with light usage. The differences in the amount of methylated cytidine in comparison to the control were: $0.40 \%, 0.16 \%$ and $-0.55 \%$, for blue, red and green light, respectively. The level of global genomic DNA methylation from control plants was in the range 21.32-21.52\%. Methylation changes in response to monochromatic light used during callus formation in anthers culture, determined by RP-HPLC, are significant although small.
\end{abstract}

Key words: RP-HPLC, Hordeum vulgare L., LED, cytidine

\begin{abstract}
Zmiany metylacji DNA to jeden z najlepiej poznanych mechanizmów epigenetycznej regulacji ekspresji genów, który $\mathrm{w}$ procesie indukowanej androgenezy związany jest $\mathrm{z}$ przeprogramowaniem rozwoju haploidalnych mikrospor w kierunku wytworzenia zarodków, w skutek ekspozycji pylników w kłosach a następnie kultur pylnikowych na czynniki stresowe. Celem przeprowadzonych badań było sprawdzenie hipotezy, czy zastosowanie światła monochromatycznego w trakcie indukowanej androgenezy może być związane ze zjawiskami epigenetycznymi. Badania przeprowadzono na roślinach DH jęczmienia jarego (Hordeum vulgare L.) uzyskanych na drodze androgenezy modyfikowanej przez światło monochromatyczne: niebieskie, zielone i czerwone. Ilościową ocenę wpływu światła na stopień metylacji DNA wykonano za pomocą RP-HPLC porównując DNA regenarantów uzyskanych w standardowych, kontrolnych, warunkach (ciemność) z DNA regenerantów uzyskanych z wykorzystaniem światła. Stwierdzono, że różnice w ilości zmetylowanej cytydyny w porównaniu do kontroli wynoszą odpowiednio $0,40 \%, 0,16 \%$ i $-0,55 \%$, dla światła niebieskiego, czerwonego i zielonego, przy poziomie całkowitej metylacji genomu 21,32-21,52\%. Zmiany całkowitej metylacji genomu jęczmienia zachodzące pod wpływem światła monochromatycznego zastosowanego na etapie formowania kalusa w procesie androgenezy w kulturach pylnikowych, oznaczone za pomocą RP-HPLC, są istotne aczkolwiek nieduże.
\end{abstract}

Slowa kluczowe: RP-HPLC, Hordeum vulgare L., LED, cytidine

\section{Introduction}

DNA methylation is a modification of deoxyribonucleic acid, which occurs during the $\mathrm{S}$ phase of the cell cycle, under the influence of DNA methyltransferases, specific against nitrogenous bases: cytosine or adenine, which are part of the nucleotides deoxycytidine $(\mathrm{dC})$ and deoxyadenosine (dA). It involves the attachment of methyl groups $\left(-\mathrm{CH}_{3}\right)$ mainly to the $5^{\text {th }}$ carbon atom in the pyrimidine ring and less frequently on the methylation of $\mathrm{NH}_{2}^{+}$groups located either at the $4^{\text {th }}$ carbon atom of cytosine or at the $6^{\text {th }}$ carbon atom of adenine (purine base). Methylation occurring in $\mathrm{CpG}$ dinucleotides and $\mathrm{CpXpG}$ trinucleotides, where $\mathrm{X}$ is $\mathrm{A}, \mathrm{T}, \mathrm{C}$ is defined as symmetrical methylation, while in $\mathrm{CpXpX}$ sequences, as unsymmetrical.

The methyl group donor is 5 '-adenosine 
methionine and the reaction products are:5-methyl-2'-deoxycytidine $(5 \mathrm{mdC})$, the main product of DNA methylation as well as $\mathrm{N}_{4}$-methyl-deoxycytidine and $\mathrm{N}_{6}$-methyl-deoxyadenosine. The amount of $5 \mathrm{mdC}$ depends on both the enzymatically catalysed methylation as well as demethylation, which may be passive or active. Passive demethylation occurs during replication and is not accompanied by melyltransferase-1 (DNMT1), thus resulting in a lack of conservative methylation (Guz et al., 2010). In contrast, active demethylation is catalyzed by bifunctional DNA glycosylases from the DEMETER family during the repair of replication errors ( $\mathrm{Li}$ et al. 2018). It is also associated with modifications of histones and, most likely, non-coding RNA (Parrilla-Doblas et al., 2019, Zhang et al. , 2012). In mammals, the share of $5 \mathrm{mdC}$ in total $\mathrm{dC}$ content is $3-4 \%$, which is $0.75-1 \%$ in relation to all nucleosides (Guz et al., 2010). It is estimated that $70-80 \%$ of $\mathrm{CpG}$ dinucleotides in the entire mammal genome are methylated (Law and Jacobsen, 2010).

On the other hand, the amount of methylated cytidine in the plant genome is $20-30 \%$ (Finnegan et al., 1998). In the Arabidopsis thaliana genome $\mathrm{CpG}, \mathrm{CpXpG}$ and $\mathrm{CpXpX}$ are methylated approximately at $24 \%, 6.7 \%$ and $1.7 \%$, respectively (Law and Jacobsen, 2010). The degree of DNA methylation changes with tissue age, wherein the methylation non-related to $\mathrm{CpG}$ islands is characteristic for differentiating cells (Peredo et al., 2006).

The androgenesis in vitro of haploid microspores allows for reprogramming their development from the gametophyte, leading to the formation of functional pollen grains, to sporophyte, leading to embryo formation. This process is accompanied by changes in genomic DNA methylation. Although in mammals most aspects of epigenetic regulation of both embryo as well as cancer cell development are quite well understood (Guz et al., 2010), the mechanisms of plant DNA methylation patterns reset remains predominantly unexplored. Changes in patterns of genomic DNA methylation in plant tissues may appear as a response to environmental stresses, associated with the redox signalling system (Bednarek and Orłowska, 2020). It has been shown that these changes are not only specific to individual species, but also differ within genotypes (Karan et al., 2012). Among others, plant regeneration by tissue culture in vitro also induces variation in the level of DNA methylation, depending on plant regeneration system, genotype of donor plants, explant, nutrient medium, as well as time duration of the culture. Among factors likely affecting changes in DNA methylation is also light. It was found that the total amount of methylated cytidine increased in DNA of barley DH regenerants obtained via androgenesis or somatic embryogenesis in comparison with the donor plant, whereas in triticale it decreased (Machczyńska et al., 2014; Orłowska et al., 2016). However, if one or more subsequent generative propagation cycles are carried out, the amount of $5 \mathrm{mdC}$ stabilizes in successive plants thus obtained. Quantitative changes of methylated DNA are accompanied by changes in methylation patterns (Bednarek i Orłowska, 2020; Machczyńska et al., 2014; Niedziela, 2018; Orłowska et al., 2016).

Quantitative determination of genomic DNA methylation can be carried out by RP-HPLC (Reversed Phase-High Performance Liquid Chromatography). This method was used for analyses of genomic DNA of cereal plants in response to abiotic stress (Niedziela, 2018), as well as in studies of barley and triticale in vitro regeneration (Orłowska et al., 2016; Machczyńska et al., 2014). The purpose of the present work was to evaluate whether modifications of the androgenesis process in anther cultures in vitro, consisting of the use of monochromatic light at the callus induction stage, affects changes in the level of methylation of genomic DNA in regenerants.

\section{Materials and Methods}

DNA from leaves of spring barley regenerants (Hordeum vulgare L.), genotype $2 \mathrm{dh} / 8$, were used for the experiment. Regenerants were obtained in anther culture in vitro, proceeded according to a modified protocol by using different monochromatic lighting at the stage of callus formation on induction medium (usually run in darkness). Regenerant plants were grown in dedicated trays with wells for single plants, in a phytotron at $18 / 14^{\circ} \mathrm{C}$ and in a $16 / 8 \mathrm{~h}$ day/night photoperiod. Leaves for DNA isolation were taken from plants in the tillering stage. The ploidy of regenerants genome was determined using a CyFlow Ploidy Analyzer flow cytometer (Sysmex Polska Sp. Z o.o.). This stage of the experiment and its detailed results are the subject of a separate publication (Siedlarz et al., 2020). Here, the subject of research was the DNA of regenerants obtained as a result of androgenesis in vitro modified at the time of callus induction by monochromatic LED light: blue $454.63 \mathrm{~nm}$, green $525.95 \mathrm{~nm}$ and red $630.84 \mathrm{~nm}$. The control group consisted DNA of regenerants obtained under standard conditions, i.e. in the dark during callus induction (Orłowska et al., 2016, Bednarek and Orłowska, 2020, Siedlarz et al., 2020). DNA was isolated from pairs of regenerates 
obtained from the anther of the same ear: 10 in control conditions and 10 in light modified conditions. A total of 60 DNA samples were isolated from leaves of plants in the tillering phase using the DNasy Mini Prepkit kit (Qiagen GmbH, Hilden, Germany), according to the manufacturer's methodology. DNA concentration and purity were determined using a UV-Vis NanoDrop 2000c/2000 spectrophotometer (Thermo Scientific, USA). The quality of the samples was verified electrophoretically in $1.4 \%$ agarose gel.

Quantitative analysis of DNA methylation was performed using RP-HPLC (Waters 625 LC system with a Waters 996 PDA detector) (Johnston et al., 2005, Orłowska et al., 2016). DNA samples denatured at $100^{\circ} \mathrm{C}$ were digested with $\mathrm{P} 1$ nuclease prior to $\mathrm{dC}$ and $5 \mathrm{mdC}$ determination after separation under isocratic conditions on a Max-RP C12 column, $4 \mu \mathrm{m}, 150 \times 4.6 \mathrm{~mm}$ (Phenomenex, USA) connected with a $4 \mu \mathrm{m}$ pre-column Max-RP C12, eluted with a linear gradient: $0-55 \%$ buffer $\mathrm{B}$ within 0-10 minutes, $55-100 \% \mathrm{~B}$ within $10.1-20$ minutes, and then with $100 \%$ buffer A for $5 \mathrm{~min}$, flow $1 \mathrm{ml} /$ min, where buffer $\mathrm{A}$ is: $0.5 \%$ methanol in $10 \mathrm{mM}$ $\mathrm{KH}_{2} \mathrm{PO}_{4} \mathrm{pH} 3.7$ and buffer B is: $10 \%$ methanol in $10 \mathrm{mM} \mathrm{KH}_{2} \mathrm{PO}_{4} \mathrm{pH}$ 3.7. Detection was carried out spectrophotometrically at $\lambda=280 \mathrm{~nm}$ and concentration [\%] of 5-methyl-2'-deoxycytidine (5mdC) was evaluated using Millennium 32 v. 4.0 software. For each sample, the percentage of total genomic DNA methylation was determined from the quotient of the content of 5-methyl-2'-deoxycytidine (5mdC) in relation to the sum of 5-methyl-2'-deoxycytidine and 2'-deoxycytidine $(\mathrm{dC}): 5 \mathrm{mdC}[\%]=[5 \mathrm{mdC} /$ $(5 \mathrm{mdC}+\mathrm{dC})] \times 100$. The results were subjected to ANOVA variance analysis and homogeneous groups were determined based on the Tukey test.

\section{Results and Discussion}

The experiment was conducted to check whether modifications of the in vitro androgenesis by the usage of monochromatic light at the callus induction stage affects changes in the level of genomic DNA methylation of regenerants. DNA which was isolated from 60 plants, more specifically 30 pairs of plants, obtained under control and light-modified conditions, were subjected to quantitative RP-HPLC analysis. Since the donor plants were characterized by a constant level of DNA methylation, as they came from generative reproduction (Orłowska et al., 2016), we assume that the modifications of methylation observed in this experiment were induced by light.

There is no information available on how many generative cycles are needed to stabilize/eliminate (if possible at all) the effects of tissue cultures on DNA methylation. Nevertheless, it has been shown that in both the barley and triticale genome the level of methylation stabilizes after one/two cycles (Machczyńska et al., 2014; Orłowska et al., 2016). Thus, to stabilize DNA methylation changes induced in regenerants genome DNA during in vitro tissue culture, the use of regenerants should be considered as donor plants. The total range of methylation changes in the barley genome determined in the present experiment was small and ranged from 21.12 to $21.87 \%$. Also, Orłowska et al. (2016) showed $17.86 \%$ of methylation of the donor plant genome of the barley cultivar Scarlett, while the range of total DNA methylation of regenerants and the next two generative generations were in the range 19.88-20.09\%. Machczyńka et al. (2014) for triticale (Bogo cultivar) showed a similar trend. Regardless of the method used for in vitro cultures (androgenesis in anther culture $v s$ embryogenesis), total DNA methylation, determined by RP-HPLC, was $25.4 \%$ in the case of donor plants. In the generatively obtained first generation it decreased to $23.6 \%$ and then slightly raised, differentiating P2 from $\mathrm{P} 1$, but no longer differentiating future generations. It should be noted that the level of total DNA methylation as well as the change in the level of methylation due to in vitro reproduction depend on the genome; e.g. the DNA methylation degree of pannanian gentian donor plants (Gentiana pannonica Scop) was $22.3 \%$, while regenerants ranged from 28.1-30.9\% (Fiuk et al., 2010). In the present experiment, the total amount of $5 \mathrm{dmC}$ in the DNA of control plants averaged $21.4 \%$ and did not differentiate the tested regenerants obtained under unmodified light conditions (Table 1). However, in the group of regenerants obtained using light at the callus induction stage, differences were observed: for blue light conditions the amount of $5 \mathrm{dmC}$ was the smallest, significantly different from the value registered for parallel control plants, while for green light it was the largest and also different from the control group (Table 1). The results obtained for the group exposed to red light were ambiguous. They did not differ significantly from the value obtained for the group of plants under blue light. However, they did not differ from the control plants either. The difference in the amount of methylated cytidine between control plants and plants regenerated using light was on average: $+0.40 \%,+$ $0.16 \%$ and $-0.55 \%$ for blue, red and green light (Fig. 1). In regenerants obtained in conditions modified by red light, differences from control ranged from 
$-0.86 \%$ to $+0.92 \%$. Those results were ambiguous and require further investigation.

The changes in the global level of cytidine methylation in cereal plants described in the literature, induced by generative reproduction, mainly concerned comparisons between donor plants and regenerants under standard conditions for particular laboratories, or between the applied plant regeneration systems. It is interesting that within the Hordeum vulgare L. species, in vitro cultivation of wild forms caused changes in cytosine methylation in both level and patterns of methylation in comparison to the donor plant, in which higher level of DNA methylation were found (Li et al., 2007). An inverse relationship was observed for the barley cultivar Scarlett, since the lowest average value of global methylation was observed in donor plants, while the average value of DNA methylation and their offspring was $20 \%$ and $20.13 \%$, respectively (Orlowska et al., 2016). Higher levels of methylation were observed in triticale

\section{Tabela 1}

Table 1

Średnia ilość zmetylowanej cytydyny [\%] w DNA genomowym regenerantów jęczmienia uzyskanych na drodze androgenezy $w$ warunkach standardowych (kontrola) oraz w warunkach modyfikowanych przez światlo monochromatyczne o barwie niebieskiej, zielonej bądź czerwonej.

The average amount of methylated cytidine [\%] in the genomic DNA of barley regenerants obtained by androgenesis under standard conditions (control) and conditions modified by blue, green or red monochromatic light.

\begin{tabular}{|c|c|c|}
\hline & \multicolumn{2}{|c|}{$5 \mathrm{dmC}[\%]$} \\
\hline & \multicolumn{2}{|c|}{$\begin{array}{l}\text { warunki androgenezy } \\
\text { androgenesis condition }\end{array}$} \\
\hline $\begin{array}{l}\text { światło } \\
\text { light }\end{array}$ & $\begin{array}{l}\text { kontrola } \\
\text { control }\end{array}$ & $\begin{array}{l}\text { światło } \\
\text { light }\end{array}$ \\
\hline $\begin{array}{l}\text { niebieskie } \\
\text { blue }\end{array}$ & $21.52 \mathrm{a}$ & $21.12 \mathrm{~b} * *$ \\
\hline $\begin{array}{l}\text { zielone } \\
\text { green }\end{array}$ & $21.32 \mathrm{a}$ & $21.87 \mathrm{a} * *$ \\
\hline $\begin{array}{l}\text { czerwone } \\
\text { red }\end{array}$ & $21.45 \mathrm{a}$ & $21.29 b^{\mathrm{nd}}$ \\
\hline
\end{tabular}

Wartości oznaczone ta sama litera nie różnia się istotnie $w$ grupie regenerantów kontrolnych (kontrola) i grupie regenerantów uzyskanych $w$ warunkach modyfikowanych świattem (światto) (liczby w kolumnie)

** istotna różnica z $P \geq 95 \%$ (nd - brak różnic) pomiędzy stopniem metylacji regenerantów uzyskanych $w$ warunkach kontrolnych a stopniem metylacji regenerantów uzyskanych $w$ warunkach modyfikowanych świattem (liczby $w$ wierszach)

Values marked with the same letter do not differ significantly in the group of control regenerants (control) and the group of regenerants obtained under conditions modified by light (light) (numbers in a column)

** significant difference with $P \geq 95 \%$ (nd - no differences) between the level of methylation of regenerants obtained under control conditions and the level of methylation of regenerants obtained under conditions modified by light (numbers in rows)
DNA for plants obtained in cultures of spontaneously released microspores, compared to regenerants from the culture of immature zygotic embryos. Differences between donor plants and regenerants have been shown. The average methylation of the genome of a donor plant was $25.4 \%$, whereas regenerants $24.1 \%$. The first generative progeny was characterized by $23.6 \%$ DNA methylation, the second $23.8 \%$, and the third generative progeny23.9\%. (Machczyńska et al., 2014). Changes in the level of genomic DNA methylation are specific for each species, and also depend on the in vitro culture conditions. Exposure to UV-B light of an annual plant, big sagebrush seedlings obtained from apical meristem shoots induced a significant reduction in the total level of DNA methylation (Pandey and Pandey-Rai, 2015). The presented results also indicate that the type of monochromatic light used during callus induction in anthers in vitro culture causes changes in the level of methylation of genomic DNA, in a manner depending on the wavelength of light used, i.e. the color of the monochromatic light.

\section{Conclusions}

The use of monochromatic light in androgenesis in vitro during the incubation of anthers on the induction medium affects small but significant changes in genomic DNA methylation. The level of methylation depends on the wavelength of the light used.

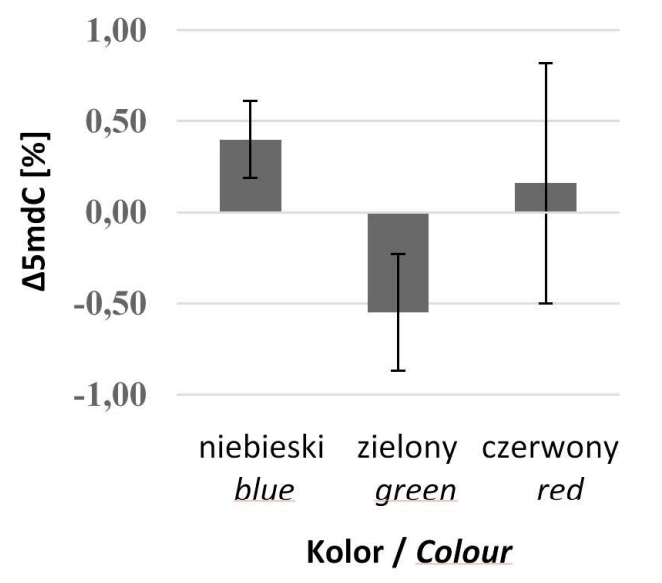

Rys. 1. Średnie różnice [\%] w ilości zmetylowanej cytydyny $w$ DNA regenerantów uzyskanych na drodze androgenezy prowadzonej $w$ warunkach kontrolnych i warunkach modyfikowanych światlem niebieskim, zielonym i czerwonym z zaznaczoną wartością odchylenia standardowego, na podstawie wyników uzyskanych dla 10 par regenerantów $z$ każdych warunków świetlnych.

Fig. 1. Average differences [\%] in the amount of methylated cytidine in the DNA of regenerants obtained by androgenesis under control conditions and conditions modified by blue, green and red lights, with marked standard deviation, based on the results obtained for 10 pairs of regenerants from each light condition. 
Some of the results were presented at the Young Scientist Days Conference 2019 in Radzików

\section{Literature}

Bednarek P. T., Orłowska R. 2020. Plant tissue culture environment as a switch-key of (epi)genetic changes. Plant Cell Tiss. Organ Cult. 140: 245 - 257.

Finnegan E. J., Genger R. K., Peacock W. J., Dennis E. S. 1998. DNA methylation in plants. Ann. Rev. Plant Physiol. Plant Mol. Biol. 49(1): 223 - 247.

Fiuk A., Bednarek P. T., Rybczyński J. J. 2010. Flow Cytometry, HPLC-RP, and metAFLP Analyses to Assess Genetic Variability in Somatic Embryo-Derived Plantlets of Gentiana pannonica Scop. Plant Mol. Biol. Rep. 28: $413-420$.

Guz J., Foksiński M., Oliński R. 2010. Mechanizm metylacji i demetylacji DNA - znaczenie w kontroli ekspresji genów [Eng.: Mechanism of DNA methylation and demethylation - its role in control of genes expression] Post. Bioch. 56(1): $7-15$.

Johnston J. W., Harding K., Bremner D. H., Souch G., Green J., Lynch P. T., Grout B., Benson E. E. 2005. HPLC analysis of plant DNA methylation: a study of critical methodological factors. Plant Physiol. Biochem. 43(9): $844-853$.

Karan R., DeLeon T., Biradar H., Subudhi P. K. 2012. Salt stress induced variation in DNA methylation pattern and its influence on gene expression in contrasting rice genotypes. PloS One 7(6): e40203.

Law J. A., Jacobsen S. E. 2010. Establishing, maintaining and modifying DNA methylation patterns in plants and animals. Nat. Rev. Gen. 11(3): $204-220$.
Li X., Yu X., Wang N., Feng Q., Dong Z., Liu L., Liu B. 2007. Genetic and epigenetic instabilities induced by tissue culture in wild barley (Hordeum brevisubulatum Trin.). Plant Cell Tiss. Organ Cult. 90(2): 153 - 168.

Machczyńska J., Orłowska R., Zimny J., Bednarek P. T. 2014. Extended metAFLP approach in studies of the tissue culture induced variation (TCIV) in case of triticale Mol. Breed. 34(3): $845-854$.

Niedziela A. 2018. The influence of $\mathrm{Al}^{3+}$ on DNA methylation and sequence changes in the triticale $(\times$ Triticosecale Wittmack) genome. J. Appl. Gen. 59(4): 405 - 417.

Orłowska R., Machczyńska J., Oleszczuk S., Zimny J., Bednarek P. T. 2016. DNA methylation changes and TE activity induced in tissue cultures of barley (Hordeum vulgare L.). J. Biol. Res.-Thessalonike 23(1): 19.

Pandey N., Pandey-Rai S. 2015. Deciphering UV-B-induced variation in DNA methylation pattern and its influence on regulation of DBR2 expression in Artemisia annua L. Planta 242(4): $869-879$.

Parrilla-Doblas J. T., Roldan-Arjona T., Ariza R. R., Cordoba-Canero D. 2019. Active DNA Demethylation in Plants. Int. J. Mol. Sci. 20(19): 4683.

Peredo E. L., Revilla M. Á., Arroyo-García R. 2006. Assessment of genetic and epigenetic variation in hop plants regenerated from sequential subcultures of organogenic calli. J. Plant Physiol. 163(10): 1071 - 1079.

Siedlarz et al. 2020 (w przygotowaniu).

Zhang H., Zhu J. K. 2012. Active DNA demethylation in plants and animals. Cold Spring Harb. Symp. Quant. Biol. 77: $161-173$. 